Гранулематоз как компонент пролиферативных реакций в печени и поджелудочной железе после частичной гепатэнтопии на фоне суперинвазионного описторхоза

Лазарев С.Д. ${ }^{1}$, Урузбаев Р.М., ${ }^{1,}$, Хадиева Е.Д. ${ }^{3,4}$, Куликова С.В. ${ }^{1}$, Косикина А.В. ${ }^{1}$, Вихарева Л.В. ${ }^{1}$, Бычков В.Г. ${ }^{1}$

${ }^{1}$ ФГБОУ ВО «Тюменский государственный медицинский университет» Минздрава России

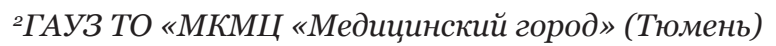

${ }^{3}$ БУ ХМАО - Югры «Окружная клиническая больница» (Ханты-Мансийск)

${ }_{4}^{4 Б У ~ В О ~ Х М А О ~-~ Ю г р ы ~ « Х а н т ы-М а н с и и ̆ с к а я ~ г о с у д а р с т в е н н а я ~ м е д и ц и н с к а я ~ а к а д е м и я » ~}$

\title{
Granulomatosis as a component of proliferative reactions in the liver and pancreas after partial hepatectomy in the setting of superinvasive opisthorchiasis
}

\author{
Lazarev S.D. ${ }^{1}$, Uruzbaev R.M., ${ }^{1,}$, Khadieva E.D. ${ }^{3,4}$, Kulikova S.V. ${ }^{1}$, Kosikina A.V. ${ }^{1}$, Vikhareva L.V. \\ Bychkov V.G. ${ }^{1}$
}

${ }^{1}$ Tyumen State Medical University

${ }^{2}$ Clinical Medical Center "Medical City" (Tyumen)

${ }^{3}$ District Clinical Hospital (Khanty-Mansiysk)

${ }^{4}$ Khanty-Mansiysk State Medical Academy

\section{АННОТАЦИЯ}

В в ед е н и е. Описторхоз на территории России имеет преимущественно суперинвазионную форму, т.е. заболевание в гиперэндемичных очагах протекает с более тяжелыми проявлениями и структурными изменениями в эконишах паразита (печень, поджелудочная железа). При суперинвазионном описторхозе (CO) у человека и животных наблюдается гранулематозное воспаление с формированием гранулем.

Ц е л ь и с с л е д о в а н и я. Выявить особенности гранулематозного процесса в печени и поджелудочной железе после частичной гепатэктомии на фоне суперинвазионного описторхоза у сирийских хомяков.

М а те риалы и м е тоды. Экспериментальные животные были разделены на 2 группы: 1-я $(n=180)-$ моделирование СО путем введения в желудок 50 метацеркариев Opisthorchis (O.) felineus, cуперинвазии 50 метацериариями $O$. felineus повторяли на 6, 16-е сутки после первичного заражения; 2-я группа $(n=86)-$ моделирование СО по той же схеме, что и для группы 1 , и частичная гепатэктомия (ЧГЭ) (удаление срединной доли органа, 17.3-17.7 \% его массы) на 16-е сутки после последней суперинвазии. Животных выводили из эксперимента на 7, 16-е, 23-и, 32, 38, 120, 240-е сутки. Изучение препаратов печени и поджелудочной железы проводилось с помощью гистологического, гистохимического, иммуногистохимического методов.

Р ез у ль т а ты . Выявлены виды, морфогенез, течение, исходы гранулем в печени и поджелудочной железе. Фактором гранулемообразования являлись секретом, яйца и метаболиты O. felineus в обеих экспериментальных группах.

З а к л ю ч е н и е. Гранулематоз при суперинвазионном описторхозе, в том числе после ЧГЭ, является эмерджентным состоянием системы паразит - хозяин вследствие накопления антигенного материала в количестве, превышающем неравновесное состояние в данной системе. Регенераторный процесс в группе после ЧГЭ на фоне СО не влияет на гранулематозное воспаление и формирование гранулем.

Ключевъе слова: описторхоз суперинвазионный, частичная гепатэктомия, поджелудочная железа, гранулематоз.

Поступила 02.12.2020

Принята 22.01.2021

Автор, ответственный за переписку

Лазарев Семен Дмитриевич: ФГБОУ ВО «Тюменский государственный медицинский университет» Минздрава России. 625023, г. Тюмень, ул. Одесская, 54 .

E-mail: raproerk@mail.ru
Received 02.12.2020

Accepted 22.01.2021

Corresponding author

Lazarev Semen Dmitriyevich: Tyumen State Medical University, 54, Odesskaya str., Tyumen, 625023, Russia.

E-mail: raproerk@mail.ru 


\section{ABSTRACT}

In trod u cti o n. Opisthorchiasis on the territory of Russia has a predominantly superinvasive form, i.e., the disease in hyperendemic foci proceeds with more severe manifestations and structural changes in the parasite's ecological niche (liver, pancreas). With superinvasive opisthorchiasis (SO) in humans and animals, granulomatous inflammation with the formation of granulomas is observed.

$\mathrm{Aim}$ of the rese a $\mathrm{ch}$. To reveal the features of the granulomatous process in the liver and pancreas after partial hepatectomy in the setting of superinvasive opisthorchiasis in Syrian hamsters.

Materials and methods. Research animals were divided into 2 groups: group $1(n=180)-S O$ modeling by introducing into the stomach of 50 Opisthorchis (O.) felineus metacercariae, superinvasions with 50 O. felineus metacercariae were repeated on the $6,16^{\text {th }}$ days after the primary infestation; group $2(n=86)-$ modeling of SO according to the same scheme as for group 1, and partial hepatectomy (PHE) (removal of the median lobe of an organ, 17.3-17.7\% from its mass) on the $16^{\text {th }}$ day after the last superinvasion. The animals were removed from the experiment on $7,16^{\text {th }}, 23^{\text {rd }}, 32^{\text {nd }}, 38$, $120,240^{\text {th }}$ day. The study of liver and pancreas preparations was carried out using histological, histochemical, immunohistochemical methods.

Results. The types, morphogenesis, course, outcomes of granulomas in the liver and pancreas were revealed. The factors of granuloma formation were the secretome, eggs and metabolites of $O$. felineus in both experimental groups.

Conclusion. Granulomatosis in superinvasive opisthorchiasis, including after PHE, is an emergent state of the parasite-host system due to the accumulation of antigenic material in an amount exceeding the nonequilibrium state in this system. The regenerative process in the group of animals after PHE in the SO setting does not affect granulomatous inflammation and the formation of granulomas.

Keywords: superinvasive opisthorchiasis, partial hepatectomy, pancreas, granulomatosis.

\section{$\mathbb{B}$ ВЕДЕНИЕ}

Описторхоз - системное паразитарное заболевание, вызываемое гельминтом из класса трематод. Подавляющая часть мирового очага описторхоза сосредоточена на территории России и Украины в 3 основных очагах: Обь-Иртышском, Волго-Камском и Днепровском, причем к гиперэндемичным относится только первый [1]. Гельминтоз, вызываемый трематодой Opisthorchis (O.) felineus (Rivolta, 1884), в гиперэндемичном очаге представлен преимущественно суперинвазионной формой, при которой в пролиферативный процесс вовлекаются все органы хозяина: человека и животных. Структурно-функциональные нарушения гомеостаза хозяев при суперинвазионном описторхозе (CO) активно изучаются специалистами многих дисциплин [1-3].

Гранулематозное воспаление встречается при туберкулезе, брюшном тифе, саркоидозе, паразитарных болезнях (шистосомоз, амебиаз) и других инвазиях. Патоморфология гранулематозного поражения печени и поджелудочной железы изучена при суперинвазионной форме описторхоза [4]. Гранулемогенез при описторхозе может быть частично модифицирован при воздействии других аллергических факторов $[5,6]$.

В экспериментальных работах морфологов достаточно полно описаны процессы регенерации печени после частичной гепатэктомии (ЧГЭ) на фоне CO: выделены 3 регенераторные зоны (A, B, C), характеризирующиеся различными

\section{INTRODUCTION}

Opisthorchiasis is a systemic parasitic disease caused by helminths from the class Trematoda. The overwhelming part of the world focus of opisthorchiasis is concentrated on the territory of Russia and Ukraine in 3 main foci: Ob-Irtysh, Volga-Kama and Dnepr, and only the first belongs to the hyperendemic [1]. Helminthiasis, caused by the fluke Opisthorchis (O.) felineus (Rivolta, 1884), in the hyperendemic focus is represented mainly by the superinvasive form, in which all organs of a host (human and animal) are involved in the proliferative process. Structural and functional disorders of host homeostasis in superinvasive opisthorchiasis (SO) are being actively studied by specialists in many disciplines [1-3].

Granulomatous inflammation occurs in tuberculosis, typhoid fever, sarcoidosis, parasitic diseases (schistosomiasis, amebiasis) and other invasions. The pathomorphology of granulomatous lesions of the liver and pancreas has been studied in the superinvasive form of opisthorchiasis [4]. Granulomogenesis in opisthorchiasis can be partially modified when influenced by other allergic factors $[5,6]$.

In the experimental works of morphologists, the processes of liver regeneration after partial hepatectomy (PHE) in the setting of SO are described quite fully: 3 regenerative zones (A, B, C), characterized by different cellular and tissue characteristics, have been identified [7-9]. Description of granulomatosis after partial hepatectomy in SO is presented schematically in a few publications [10]. 
клеточными и тканевыми особенностями [7-9]. Описание гранулематоза после частичной гепатэктомии на фоне $\mathrm{CO}$ представлено схематично в единичных публикациях [10].

\section{ЦЕЛЬ ИССЛЕДОВАНИЯ}

Выявить особенности гранулематозного процесса в печени и поджелудочной железе после частичной гепатэктомии на фоне суперинвазионного описторхоза у сирийских хомяков.

\section{МАТЕРИАЛЫ И МЕТОДЫ}

Личинки O. felineus выделяли по методам Г.А. Глазкова и S. Pracobwong et al. CO моделировали у половозрелых сирийских хомяков $(n=180)$ путем введения в желудок 50 метацеркариев O. felineus, суперинвазии 50 метацеркариями повторяли на 6-е и 16-е сутки после первичного заражения - 1-я группа. Частичную гепатэктомию - удаление срединной доли печени (17.317.7 \% массы органа) - проводили 86 хомякам с СО (который моделировали по той же схеме, что и для группы 1) по методу малой резекции G.M. Higgins, R.M. Anderson [11] на 16-е сутки после последней суперинвазии - 2-я группа. Животных выводили из эксперимента путем передозировки наркозом на 7, 16-е, 23-и, 32, 38, 120, 240-е сутки после начала эксперимента.

Эксперименты на животных проводились в соответствии с принципами Европейской конвенции по защите позвоночных животных, используемых для экспериментальных и других целей (Страсбург, 1986), приказом Министерства здравоохранения РФ от 1 апреля 2016 г. № 199н «Об утверждении Правил надлежащей лабораторной практики», после получения разрешения этического комитета ФГБОУ ВО «Тюменский государственный медицинский университет» Минздрава России.

Ткань печени и поджелудочной железы фиксировали в 10\% растворе нейтрального формалина, после парафиновой проводки изготавливались срезы, которые окрашивали гематоксилином и эозином, по Ван Гизону, Слинченко, Самсонову, реактивом Шиффа. После стандартного гистологического исследования проводилось иммуногистохимическое исследование (ИГХ) на депарафинированных срезах толщиной 4-5 мкм. Депарафинирование, демаскировку антигенов и ИГХ-реакции проводили с использованием автостейнера Leica Bond-Max. В качестве первичных антител использовали мышиные моноклональные антитела к Ki-67 (клон OV-TL 12/30, Agilent/ Dako, RTU (ready-to-use - готовый к использова-

\section{AIM OF THE RESEARCH}

To reveal the features of the granulomatous process in the liver and pancreas after partial hepatectomy in case of superinvasive opisthorchiasis in Syrian hamsters.

\section{MATERIALS AND METHODS}

O.felineus larvae were isolated according to the G.A. Glazkov and S. Pracobwong et al. methods. SO was modeled in mature Syrian hamsters $(n=180)$ by introducing 50 metacercariae of $O$. felineus into the stomach, then superinvasions with 50 metacercariae were repeated on the $6^{\text {th }}$ and $16^{\text {th }}$ days after the primary infestation - group 1. Partial hepatectomy - removal of the median liver lobe (17.3$17.7 \%$ of the organ weight) - was carried out in 86 hamsters with SO (which was modeled according to the same scheme as for group 1) by G.M. Higgins, R.M. Anderson method of small resection [11] on the $16^{\text {th }}$ day after the last superinvasion - group 2. The animals were removed from the experiment by lethal overdose of anesthesia on the $7,16^{\text {th }}, 23^{\text {rd }}$, $32^{\text {nd }}, 38,120^{\text {th }}$, and $240^{\text {th }}$ days after the start of the experiment.

Experiments on animals were carried out in accordance with the principles of the European Convention for the Protection of Vertebrate Animals used for Experimental and Other Purposes (Strasbourg, 1986), by the Order of the Ministry of Health of the Russian Federation from April 1, 2016 No. 199n "On Approval of Rules of Good Laboratory Practice", after receiving permission of the ethical committee of the Tyumen State Medical University.

The liver and pancreas tissues were fixed in $10 \%$ solution of neutral formalin, after paraffin embedding sections were made, which were stained with hematoxylin and eosin, according to Van Gieson, Slinchenko, Samsonov, and with Schiff's reagent. After a histological examination, an immunohistochemistry (IHC) was performed on dewaxed sections of 4-5 $\mu \mathrm{m}$ thick. Dewaxing, antigen unmasking, and IHC reactions were carried out using a Leica Bond-Max auto-stainer. Mouse monoclonal antibodies to Ki-67 (clone OV-TL 12/30, Agilent / Dako, RTU (ready-to-use)), CD31 (clone JC70, Cell Marque, dilution $1:$ 100), CD34 (clone QBEnd / 10, Cell Marque, dilution $1: 100$ ), Oct-4 (clone MRQ10, Cell Marque, dilution $1: 200$ ), rabbit monoclonal antibodies to CD117 (clone YR145, Cell Marque, dilution $1: 500)$ and rabbit polyclonal antibodies to insulin (Cloud-Clone Corp., dilution $1: 100$ ), alphafetoprotein (Agilent/Dako, RTU) were used as primary antibodies. After the IHC reaction, the cell 
нию)), CD31 (клон JC70, Cell Marque, разведение 1 : 100), CD34 (клон QBEnd/10, Cell Marque, разведение $1: 100$ ), Oct-4 (клон MRQ-10, Cell Marque, разведение $1: 200$ ), кроличьи моноклональные антитела к CD117 (клон YR145, Cell Marque, разведение $1: 500$ ) и кроличьи поликлональные антитела к инсулину (Cloud-Clone Corp., разведение $1: 100$ ), альфа-фетопротеину (Agilent/Dako, RTU). После проведения ИГХ-реакции ядра клеток докрашивали гематоксилином Майера.

Оценку ИГХ-реакции проводили с использованием полуколичественных и количественных методов. Оценивалась интенсивность реакции по шкале от о до 3 баллов (о - реакция отсутствует, 1 - слабая, 2 - умеренная, 3 - выраженная реакция) и количество позитивно окрашенных клеток в 1 поле зрения (при увеличении (ув.) ×400). Подсчет числа позитивно окрашенных клеток выполнялся на 10 полях зрения, ув. $\times 400$ и рассчитывалось среднее арифметическое. Для определения достоверности различий средних величин использовали параметрические и непараметрические статистические критерии (Стьюдента, Манна - Уитни). Различия считались статистически значимыми при $p<0.05$.

Площадь воспалительных инфильтратов (ПВИ), площадь гранулем (ПГ) и площадь некрозов в гранулемах (ПНГ) определяли с помощью программного обеспечения для цитологического анализа в медицине и биологии Vision Cyto (West Medica Produktions- und Handels-GmbH, Австрия) в мкм² $^{2}$ вычисляли индексы этих образований как отношение ПВИ (ПГ, ПНГ) к площади препарата в поле зрения микроскопа при ув. ×50.

\section{РЕЗУЛЬТАТЫ И ОБСУЯКДЕНИЕ}

Выявлено, что в процессе регенерации в культе печени на фоне некротических и пролиферативных процессов развивается гранулематозное воспаление.

В зоне А преобладают гранулемы инородных тел как реакция на неантигенный материал (без признаков иммунного ответа). Единичные макрофаги скапливаются вдоль шовных нитей (кетгут) и формируют неиммунные гранулемы (рис. 1). К 20-м суткам после ЧГЭ формируются гигантские многоядерные клетки (ГМК) инородных тел с многочисленными ядрами, рассеянными по цитоплазме, но не по периферии, в отличие от гигантских клеток Лангханса. Клеточная активность в этих гранулемах минимальна, так как шовный материал не подвержен ни фагоцитозу, ни ферментативной обработке. В гранулемах инородных тел не выявлено некрозов, в бо- nuclei were counterstained with Mayer's hematoxylin.

Assessment of the IHC reaction was performed using semi-quantitative and quantitative methods. The intensity of the reaction was assessed on a scale from o to 3 points (o - no reaction, 1 - weak, $2-$ moderate, 3 - pronounced reaction), and by the number of positively stained cells in 1 field of view (at magnification (magn.) ×400). The number of positively stained cells was counted in 10 fields of view, at magnification $\times 400$ and the arithmetic mean was calculated. To determine the reliability of differences in mean values, parametric and nonparametric statistical tests were used (Student's test, Mann-Whitney test). Differences were considered statistically significant at $p<0.05$.

The inflammatory infiltrates' area (IIA), granulomas' area (GA) and necrosis area in granulomas (NAG) were determined using the software for cytological analysis in medicine and biology Vision Cyto (West Medica Produktions- und Handels-GmbH, Austria) in $\mu \mathrm{m}^{2}$, the indices of these formations were calculated as the ratio of IIA (GA, NAG) to the area of the specimen in the field of view of the microscope at magnification $\times 50$.

\section{RESULTS AND DISCUSSION}

It was revealed that during the regeneration in the liver stump along with the observed necrotic and proliferative processes, the granulomatous inflammation develops.

In zone A, granulomas of foreign bodies predominate as a reaction to non-antigenic material (without signs of an immune response). Single macrophages accumulate along the suture threads (catgut), and form non-immune granulomas (Fig. 1). By the $20^{\text {th }}$ day after PHE, multinucleated giant cells (MGCs) of foreign bodies with numerous nuclei scattered throughout the cytoplasm, but not along the periphery, are formed, in contrast to Langhans giant cells. Cellular activity in these granulomas is minimal, since the suture material is not subject to either phagocytosis or enzymatic treatment. No necrosis was found in the granulomas of foreign bodies; at a later date $\left(120^{\text {th }}\right.$ day), they were prone to gross sclerosis. In zone A, the formation of structures from the elements of the hepatocellular cell lineage (HCL) is observed: single regenerative formations from hepatocytes with a positive reaction to $\alpha$-fetoprotein and rich in glycogen. Tubules with alcian-positive secretion are differentiated from the committed cells.

The granulomatous process in the liver with $\mathrm{SO}$ and after PHE in the SO setting begins at the loci of 


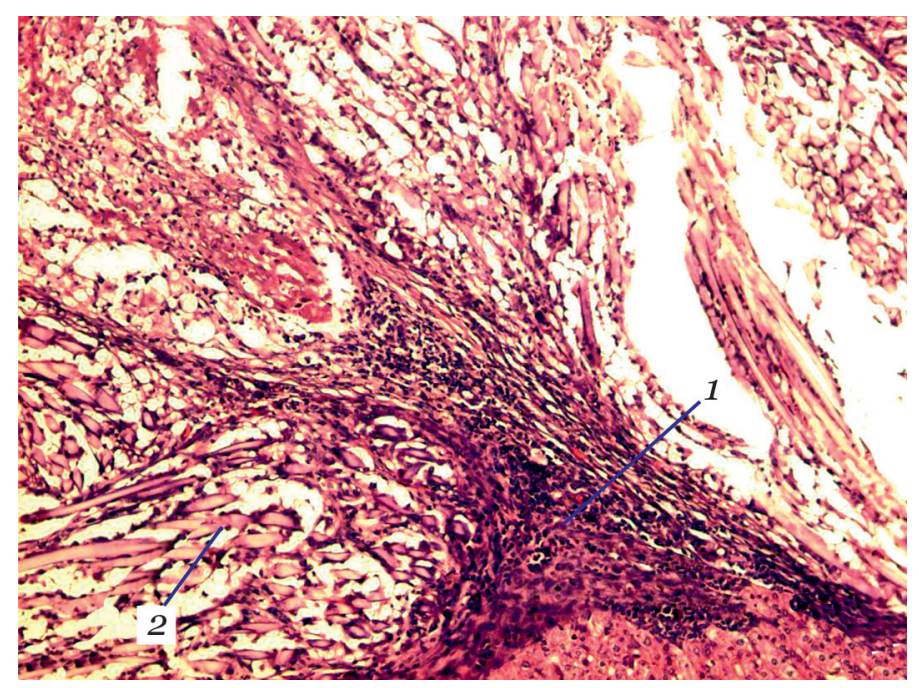

Рис. 1. ЧГЭ на фоне СО. Зона А. Неинфекционная гранулема (1) вокруг шовного материала (2). 32-е сутки инвазии. Окраска гематоксилином и эозином. Ув. ×200

Fig. 1. PHE in the SO setting. Zone A. Non-infectious granuloma (1) around suture material (2). $32^{\text {nd }}$ day of invasion. Staining with hematoxylin and eosin. Magnification (magn.) $\times 200$

лее поздние сроки (120-е сутки) они подвержены грубому склерозу. В зоне А наблюдается формирование структур из элементов гепатоцеллюлярного дифферона (ГЦД): единичные регенераторные образования из гепатоцитов с положительной реакцией на $\alpha$-фетопротеин, богатые гликогеном. Из коммитированных клеток дифференцируются трубочки с альциан-позитивным секретом.

Гранулематозный процесс в печени при СО и после ЧГЭ на фоне СО развивается в локусах контакта тегумента паразита со слизистой оболочкой протоков. К 7-м суткам инвазии $O$. felineus занимает неподвижную позу (постуральный доминантный рефлекс по Ж. Дюрану). Методом трансмиссионной и сканирующей электронной микроскопии М.М. Щудло [12] удалось выявить несколько видов шипиков тегумента $O$. felineus, среди которых имеются образования с отверстиями, уходящими в тело паразита, через которые происходит инокуляция секреторных продуктов в подстилающие эпителий ткани, что создает таким образом локусы повышенного антигенного потенциала, инициирующего гранулематозное воспаление. В этом локусе стенки протока наблюдается уменьшение высоты цилиндрического эпителия и формируются участки денудации, что объясняется процессами пристеночного пищеварения, свойственного трематодам (рис. 2).

Развитие иммунного воспаления у животных обеих групп по линии денудации (обнажения) является ответной реакцией на антигенный субстрат (секретом), поступающий из паразита. В этих участках появляются небольшие скопле- contact of the parasite tegument with the mucous membrane of the ducts. By the $7^{\text {th }}$ day of invasion, $O$. felineus takes a motionless position (postural dominant reflex according to G. Durand). By means of the method of transmission and scanning electron microscopy M.M. Shchudlo [12], we have identified several types of tegument spines of $O$. felineus, among which there were formations with holes that extend into the body of the parasite, through which secretory products are inoculated into the underlying tissues of epithelium, thus creating loci of increased antigenic potential that initiates granulomatous inflammation. In this locus of the duct wall, a decrease in the height of the cylindrical epithelium is observed and areas of denudation are formed, which is explained by the processes of parietal digestion characteristic of trematodes (Fig. 2).

The development of immune inflammation in animals of both groups along the denudation line (exposure) is a response to an antigenic substrate (secretome) coming from the parasite. In these areas, small clusters of monocytes, macrophages, eosinophilic and neutrophilic leukocytes, mononuclear cells appear, just an interductal (intramural) granuloma is formed, which, after replacing erosion with cholangiocytes, is sclerosed. Interductal granulomas are not subject to necrosis. The largest area index of such granulomas in both groups did not exceed 0.068 .

After 15 days, $O$. felineus acquires the second variant of the dominant reflex, nutriceutical, which allows the helminth to tear off large layers of mucosal epithelium with the help of an oral sucker (Fig. 3). The area of exposure increases significantly and is 


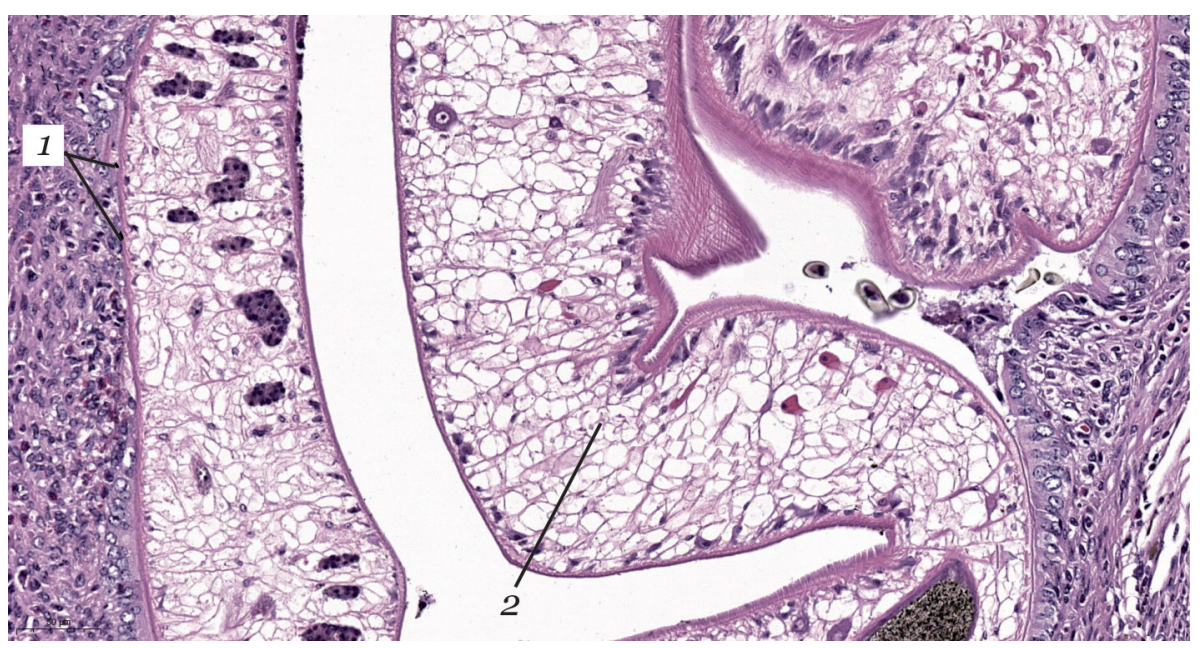

Рис. 2. ЧГЭ на фоне СО. Неполовозрелый описторхис тесно прилегает к стенке протока с формированием очагов денудации (1), половозрелый паразит (2). 7-е сутки инвазии. Окраска гематоксилином и эозином. Ув. ×270

Fig. 2. PHE in the setting of SO. Immature O. felineus closely adjoins the duct wall with the formation of denudation foci (1), the mature parasite (2). $7^{\text {th }}$ day of invasion. Staining with hematoxylin and eosin. Magn. $\times 270$

ния моноцитов, макрофагов, эозинофильных и нейтрофильных лейкоцитов, мононуклеаров формируется интердуктальная (внутристеночная) гранулема, которая после замещения эрозии холангиоцитами склерозируется. Интердуктальные гранулемы не подвергаются некрозу. Наибольший индекс площади таких гранулем в обеих группах не превышал о.068.

После 15 сут описторхис приобретает нутрицевтивный - второй вариант доминантного рефлекса, что позволяет гельминту при помощи ротовой присоски отрывать большие пласты эпителия слизистой оболочки (рис. 3). Площадь обнажения значительно увеличивается и неизменно сопровождается бо́льшим поступлением секрето- invariably accompanied by a greater inflow of secretome into the duct wall, which causes a more pronounced immune response, proliferation of CD31, CD34, CD117, Oct 4-positive cells, their differentiation, organization and pronounced inflammation with the development of intraductal granulomas from mesenchymal components covered with cellular elements of the cholangiocellular lineage. Single giant multinucleated cells with fragments of $O$. felineus eggs in the cytoplasm are observed.

The most evident granulomatous inflammation and the formation of granulomas are detected in zone B. In the vast area between the liver stump (zone A) and hepatocytes areas (zone C), cholangiectases with an area of up to $6201.83 \mu \mathrm{m}^{2}$ are formed,

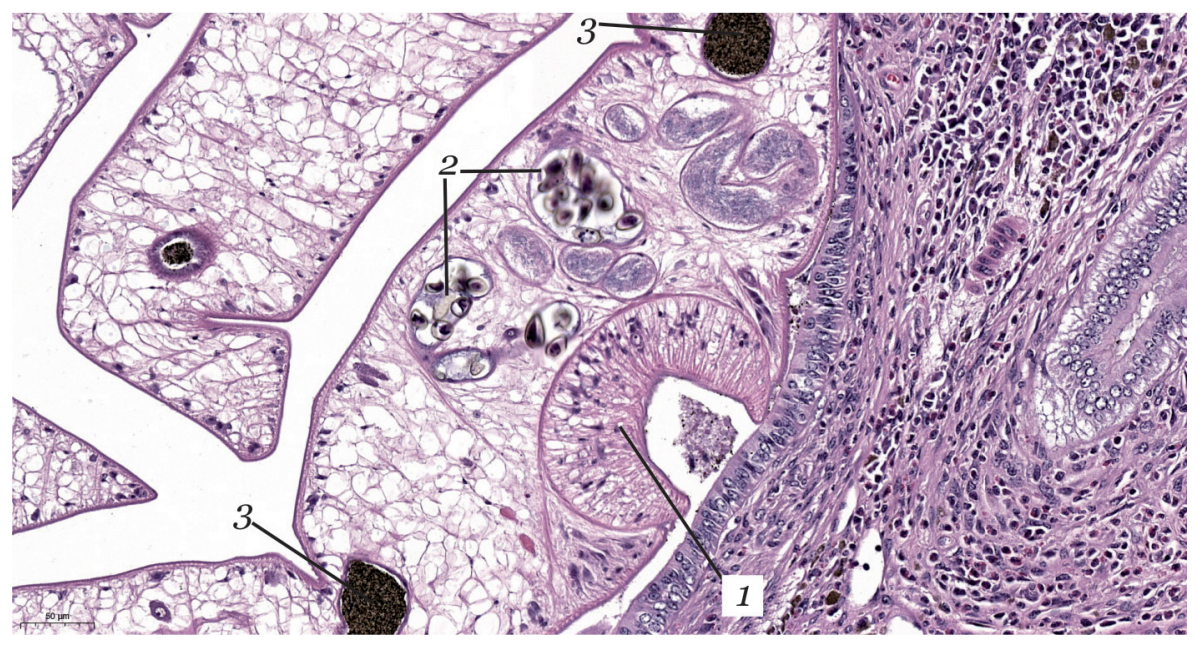

Рис. 3. ЧГЭ на фоне СО. Паразит в протоке. Готовность к отрыву слизистой оболочки (1). Яйца в матке (2). Экзометаболиты в кишке (3). 35-е сутки инвазии. Окраска гематоксилином и эозином. Ув. ×240

Fig. 3. PHE in the SO setting. The parasite is in the duct. Readiness to tear off the mucous membrane (1). Eggs in the uterus (2). Exometabolites in the gut (3). $35^{\text {th }}$ day of invasion. Staining with hematoxylin and eosin. Magn. $\times 240$ 
ма в стенку протоков, что вызывает более выраженный иммунный ответ, пролиферацию CD31, CD34, CD117, Oct 4-позитивных клеток, их дифференциацию, организацию и формирование выраженного воспаления с образованием интрадуктальных (внутрипротоковых) гранулем, состоящих из мезенхимальных компонентов, покрытых клеточными элементами холангиоцеллюлярного дифферона. Наблюдаются единичные гигантские многоядерные клетки с фрагментами яиц O.felineus в цитоплазме.

Наиболее выраженное гранулематозное воспаление и формирование гранулем выявляется в зоне В. На обширной территории между культей печени (зона А) и участками гепатоцитов (зона С) формируются холангиоэктазы площадью до 6201.83 мкм $^{2}$, стенки которых истончались до 62.38 мкм $^{2}$ (ув. ×50). В зоне В фиксируется наибольший индекс площади пролифератов - o.315, в состав которых входят CD31, CD34, CD117, Oct 4-позитивные клетки, лимфоциты, моноциты, эозинофильные и нейтрофильные лейкоциты. При частичной резекции на фоне СО в зоне В наиболее выражены гранулематозное воспаление и гранулемогенез по сравнению с зоной А.

Интрадуктальные (внутрипротоковые) гранулемы (ИГ), как и предыдущие 2 вида гранулем, встречаются в 100 \% наблюдений. Различали мелкие, средние и крупные интрадуктальные гранулемы в зависимости от степени заполнения просвета протока: мелкие закрывают просвет протока на $10 \%$, средние - на $25 \%$, крупные занимают более 1/4 площади просвета. Кроме гранулем внутри протока наблюдаются гиперпластические образования - псевдососочковые структуры. Истинные сосочки (рис. 4) могут быть на тонкой и толстой ножках, что обусловлено экспрессией пролиферативных генов, вызванной секретомом паразита. Кроме того, в просвете протоков формируются полипозные структуры - результат хронического продуктивного воспаления и, возможно, гиперрегенерации производных многих закладок. Выраженность гиперпластических процессов в целом была одинаковой как в 1-й, так и во 2-й группе животных.

Индекс ПГ зоны В при СО варьирует от 0.47 до $0.58(M e=0.36)$. Фактором образования внутрипротоковых гранулем являлись яйца и экзометаболиты O. felineus. Гранулемы данной локализации крепятся к стенке протока посредством тонкой или широкой ножек (рис. 5, 6). При гранулематозном воспалении вокруг яиц паразитов O. felineus наблюдается феномен Сплендора Хепли - скопление эозинофильной гомогенной the walls of which have thinned to $62.38 \mu \mathrm{m} 2$ (magn. $\times 50$ ). In zone $B$, the highest index of the area of proliferative tissue is recorded -0.315 , which consists of CD31, CD34, CD117, Oct 4-positive cells, lymphocytes, monocytes, eosinophilic and neutrophilic leukocytes. In partial resection in the SO setting, the most pronounced granulomatous inflammation and granulomogenesis is observed in zone B as compared to zone A.

Intraductal granulomas (IG), like 2 types previously described, are found in $100 \%$ of cases. We differentiate between small, medium and large intraductal granulomas depending on the degree of filling the duct lumen: small ones close the duct lumen by $10 \%$, medium - by $25 \%$, large ones occlude more than $1 / 4$ of the lumen area. In addition to granulomas, hyperplastic formations - pseudo-papillary structures are observed inside the duct. True papillae (Fig. 4) can be on thin and thick pedicles, which is due to the expression of proliferative genes, caused by the secretome of the parasite. In addition, polypous structures are formed in the lumen of bile ducts - a result of chronic proliferative inflammation and, possibly, hyperregeneration of derivatives of many anlagen. The intensity of hyperplastic processes was generally the same in both the $1^{\text {st }}$ and $2^{\text {nd }}$ groups of animals.

The GA index of zone B with $\mathrm{SO}$ varies from 0.47 to $0.58(M e=0.36)$. O. felineus eggs and exometabolites were a factor of the intraductal granulomas formation. Granulomas of this localization are attached to the duct wall by means of thin or thick peduncles (Fig. 5, 6). In granulomatous inflammation around the eggs of $O$. felineus, the eosinophilic homogeneous fluid accumulation is observed, which is associated with the immune response - the formation of an antigen-antibody-complement complex (Splendore-Hoeppli phenomenon).

Intraductal granulomas in the process of formation were covered with cholangiocytes, further on small areas of denudation were found, granulomas were subject to necrosis. The NAG index reached 0.303 , the maximum value of this index -0.430 was in large granulomas $(M e=0.318)$. Necrosis of intraductal granulomas depended mainly on the state of blood supply caused by sclerosis of a peduncle. Granulomas with a short peduncle were sclerosed with less pronounced necrotic changes.

The granulomas of the portal tracts occupy separate loci. The granulomas area index did not exceed 0.14. Sclerosis occurred without preexisting necrosis.

Periductal granulomas form around small and medium-sized ducts. The exometabolites and eggs of O. felineus were factors in the formation of such 


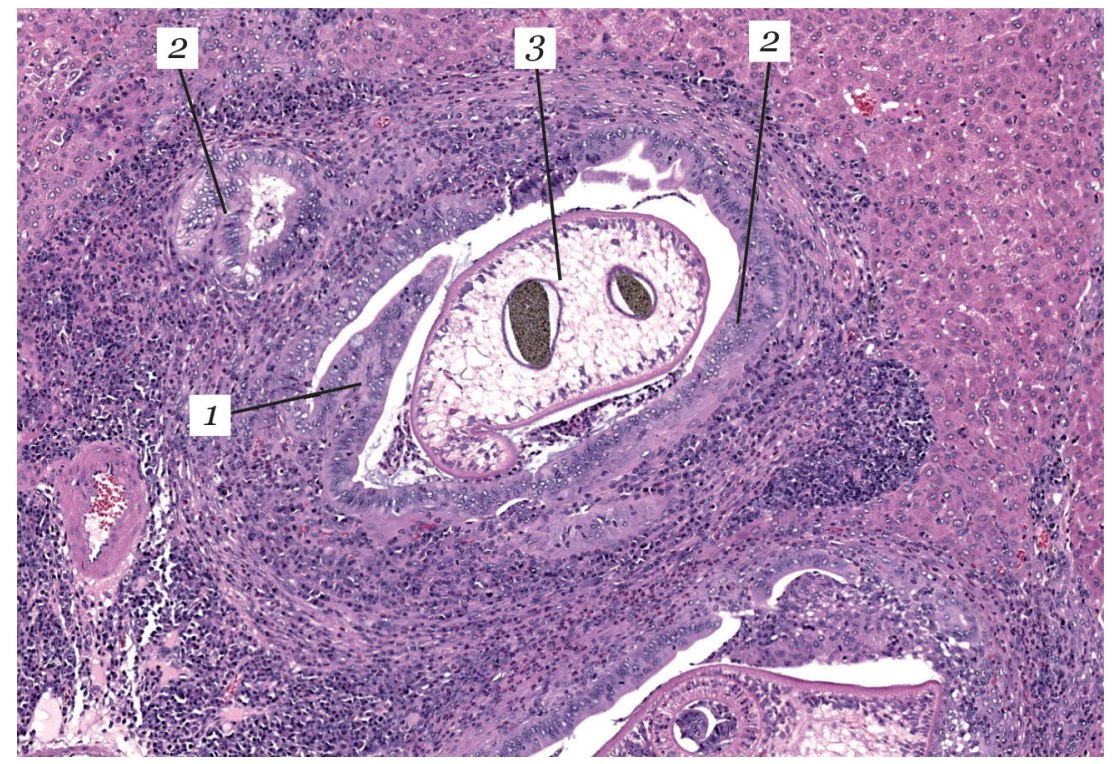

Рис. 4. ЧГЭ на фоне СО. Формирующийся истинный сосочек (1), гиперплазия слизистых оболочек (2), половозрелый описторхис в протоке (3). 38-е сутки инвазии. Окраска гематоксилином и эозином. Ув. ×200 Fig. 4. PHE in the SO setting. The forming true papilla (1), hyperplasia of the mucous membranes (2), the mature O. felineus in the duct (3). $38^{\text {th }}$ day of invasion. Staining with hematoxylin and eosin. Magn. $\times 200$

жидкости, что связано с иммунной реакцией образованием комплекса антиген - антитело комплемент.

Интрадуктальные гранулемы в процессе формирования были покрыты холангиоцитами, в дальнейшем наблюдались небольшие участки денудации, гранулемы были подвержены некрозу. Индекс ПНГ достигал 0.303, максимальное значение этого индекса $-0.430-$ в крупных гранулемах $(M e=0.318)$. Некроз внутрипротоковых гранулем зависел преимущественно от состояния кровоснабжения, обусловленного склерозом ножки. Гранулемы с короткой ножкой склерози- granulomas. The granulomas area index varied in a wide range: from 0.31 to 0.42 . Morphogenesis of granulomas underwent a characteristic evolution: "florid" macrophagal granuloma, then necrotizing and sclerosing ones.

In zone $\mathrm{C}$, the predominant processes include the regeneration of the parenchyma, first of all, the activity of the hepatocellular lineage and the formation of avascular islets from hepatocytes, adenomas (islets with a capsule), the absence of the trabecular structure of the hepatocyte fields. Granulomatous inflammation was practically not observed, there were only small formations (parenchymal granulomas)

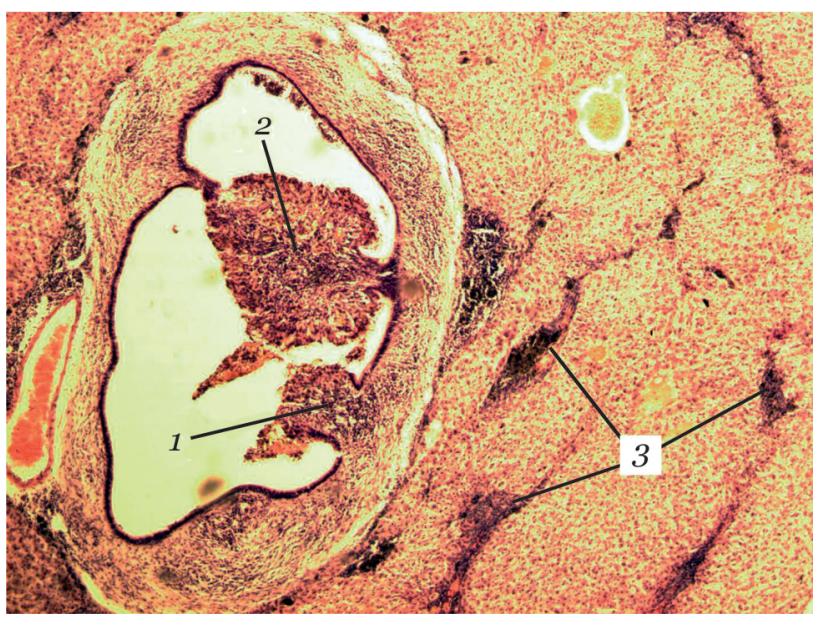

Рис. 5. ЧГЭ на фоне СО. Интрадуктальные гранулемы на ножках $(1,2)$. Очаговые скопления иммунокомпетентных и прогениторных клеток (3). 38-е сутки инвазии. Окраска гематоксилином и эозином. Ув. ×100

Fig. 5. PHE in the SO setting. Peduncled intraductal granulomas $(1,2)$. Focal aggregates of immunocompetent and progenitor cells (3). $38^{\text {th }}$ day of invasion. Staining with hematoxylin and eosin. Magn. $\times 100$ 


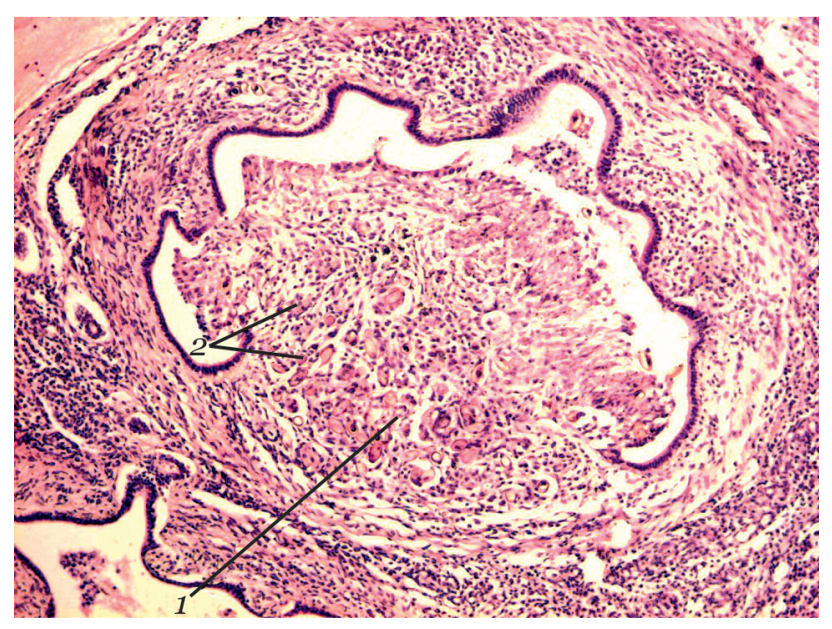

Рис. 6. ЧГЭ на фоне СО. Крупная гранулема на широкой ножке (1). Яйца в составе гранулемы (2). 120 -е сутки инвазии. Окраска гематоксилином и эозином. Ув. ×140

Fig. 6. PHE in the SO setting. Large granuloma with a wide peduncle (1). Eggs in the granuloma (2). $120^{\text {th }}$ day of invasion. Staining with hematoxylin and eosin. Magn. $\times 140$

ровались с менее выраженными некротическими изменениями.

Гранулемы портальных трактов занимают отдельные локусы. Индекс площади гранулем не превышал 0.14. Склерозирование происходило без предсуществующего некроза.

Перидуктальные гранулемы формируются вокруг протоков мелкого и среднего калибров. Фактором образования таких гранулем были экзометаболиты и яйца O.felineus. Индекс площади гранулем колебался в широком диапазоне: от 0.31 до 0.42. Морфогенез гранулем претерпевал характерную эволюцию: «цветущая» (макрофагальная) гранулема, некротизирующая и склерозирующая.

В зоне С к преобладающим процессам следует отнести регенерацию паренхимы, прежде всего - активность гепатоцеллюлярного дифферона и формирование аваскулярных островков из гепатоцитов, аденом (островки с капсулой), отсутствие балочного строения полей гепатоцитов. Гранулематозное воспаление практически не отмечалось, встречались лишь небольших размеров образования (паренхиматозные гранулемы) вследствие мелких некрозов в предсуществующей паренхиме - результат реакции немедленного типа при $\mathrm{CO}$, значительно реже гранулемы достигали больших размеров (рис. 7).

В поджелудочной железе встречаются только паренхиматозные, интраканаликулярные и периканаликулярные гранулемы. Эволюция данных гранулем идет по указанным выше этапам: «цветущая» (макрофагальная) гранулема, некротизирующая и склерозирующая, что способствует распространению фибропластических процессов в органе. Общими для всех гранулем due to small necroses in the preexisting parenchyma as a result of immediate hypersensitivity reaction in $\mathrm{SO}$, granulomas reached large sizes much less often (Fig. 7).

In pancreas, only parenchymal, intracanalicular and pericanalicular granulomas are found. The evolution of these granulomas follows the stages indicated above: macrophagal granuloma, necrotizing and sclerosing, which contributes to the spread of fibroplastic processes in the organ. Common to all granulomas are the factors of their occurrence and development: secretome, eggs and metabolites of the cat liver fluke.

\section{CONCLUSION}

The considered granulomatosis in 2 experimental groups of animals from the standpoint of the parasite-host system should be attributed to its emergent properties. Granulomatous inflammation and granulomas occur as a result of the accumulation of antigenic material in an amount significantly exceeding the nonequilibrium state in the parasite-host system. For the opisthorchis, the formation of granulomas is not key for the accumulation of nutraceutical substrate. O. felineus, like all representatives of the family Opisthorchiidae, uses cholangiocytes and bile as a nutraceutical, since "the genomes of these helminths contain genes encoding a set of enzymes and receptors necessary for the absorption, binding and/ or transformation of nutrients that are only components of bile and epithelium of the bile ducts" [13]. Representatives of the genus Opisthorchis can accidentally capture their own eggs, another duct substrate, including erythrocytes and other blood cells with the oral sucker. 


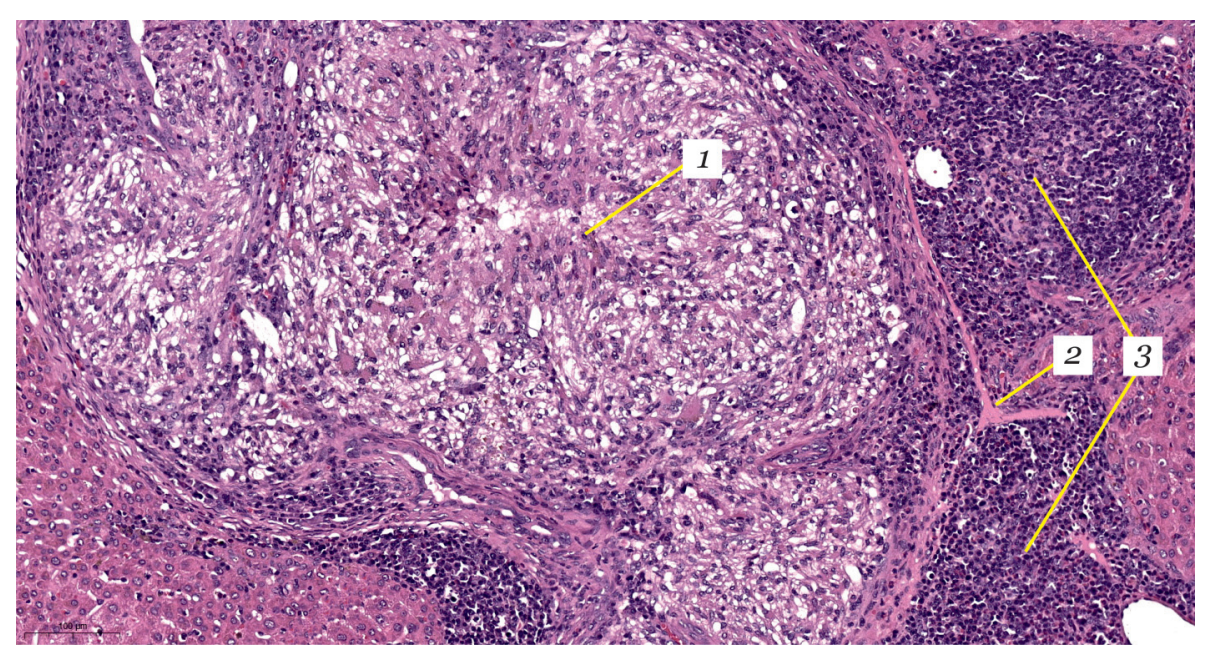

Рис. 7. ЧГЭ на фоне СО. Зона С. Паренхиматозная гранулема (1). Васкулогенез (2). Выраженное иммунное воспаление (3). 120-е сутки инвазии. Окраска гематоксилином и эозином. Ув. ×150

Fig. 7. PHE in the SO setting. Zone C. Parenchymal granuloma (1). Vasculogenesis (2). Severe immune inflammation (3). $120^{\text {th }}$ day of invasion. Staining with hematoxylin and eosin. Magn. $\times 150$

являются факторы их возникновения и развития: секретом, яйца и метаболиты описторхисов.

\section{ЗАКЛЮЧЕНИЕ}

Рассматриваемый гранулематоз в 2 экспериментальных группах животных с позиций системы паразит - хозяин следует отнести к ее эмерджентным свойствам. Гранулематозное воспаление и гранулемы возникают в результате накопления антигенного материала в количестве, значительно превышающем неравновесное состояние в системе паразит - хозяин. Для описторхисов формирование гранулем не является ключевым для накопления нутрицевтического субстрата. O. felineus, как и все описторхиды, использует в качестве нутрицевтического продукта холангиоциты и желчь, поскольку «в геномах этих гельминтов представлены гены, кодирующие набор ферментов и рецепторов, необходимых для поглощения, связывания и/или превращения питательных веществ, являющихся только компонентами желчи и эпителия желчных протоков» [13]. Описторхисы случайно могут захватить ротовой присоской собственные яйца, другой субстрат протока, в том числе эритроциты и иные клетки крови.

\section{СПИСОК ЛИТЕРАТУРЫ}

1. Козлова И.И., Остапенко Н.А., Сисин Е.И., Ежова О.А., Гузеева Т.М. К вопросу о проблеме описторхоза в гиперэндемичном очаге // Мед. паразитология и паразитарные болезни. 2017. № 3. С. 14-19.

2. Бычков В.Г., Лазарев С.Д., Хадиева Е.Д. и др. Морфологические изменения билиарной системы при суперинвазионном описторхозе // Клиническая и экспериментальная морфология. 2018. Т. 7, № 1. C. $19-24$.
Partial hepatectomy undoubtedly affects the system, but does not increase the host's antigenic concentration, since granulomas of zone A are nonimmunogenic, and the quantitative characteristics of granulomas in other zones do not exceed those in hamsters with only superinvasive opisthorchiasis. Partial hepatectomy in SO does not increase granulomatous inflammation.

Conflict of interest. The authors declare no conflict of interest.

Частичная гепатэктомия, несомненно, влияет на систему, но не усиливает антигенную насыщенность хозяина, так как гранулемы зоны А являются неиммуногенными, а количественные характеристики гранулем в других зонах не превышают таковые у хомяков только с суперинвазионным описторхозом. Частичная гепатэктомия на фоне $\mathrm{CO}$ не усиливает гранулематозное воспаление.

Конфликт интересов. Авторы заявляют об отсутствии конфликта интересов.

\section{REFERENCES}

1. Kozlova I.I., Ostapenko N.A., Sisin E.I., Ezhova O.A., Guzeeva T.M. (2017). On the problem of opisthorchiasis in a hyperendemic focus. Medical Parasitology and Parasitic Diseases, 3, 14-19.

2. Bychkov V.G., Lazarev S.D., Khadieva E.D. et al. (2018). Morphological changes of the bilial system in superinvasive opisthorchiasis. Clinical and Experimental Morphology, 7(1), 19-24. 
3. Bychkov V.G., Kalyonova L.F., Khadieva E.D. et al. Dynamics of the $O$. felineus infestation intensity and egg production in carcinogenesis and partial hepatectomy in the setting of superinvasive opisthorchiasis // Anal. Cell. Path. 2019. Art . number: ID 8078368.

4. Спирина Ю.С. Состояние желчных протоков при суперинвазионном экспериментальном описторхозе // Университетская медицина Урала. 2020. № 1 (20). С. 7-8.

5. Козлова И.И., Зуевский В.П. Особенности формирования гранулем при описторхозной инвазии на фоне аллергизации тулярином при экспериментальном описторхозе // Морфология. 2020. Т. 157, № 2-3. C. $103-104$.

6. Харитонова А.В., Зуевская Т.В. Особенности формирования гранулем при описторхозной инвазии на фоне аллергизации туберкулином при экспериментальном описторхозе // Морфология. 2020. T. 157 , № 2-3. C. 225.

7. Lazarev S.D., Alekberov R.I. Features of liver regeneration after partial hepatectomy against the background of superinvasive opisthorchiasis. Regenerative zone B // 4th International Medical Congress: Abstracts. Baku, 2017. P. 141-142.

8. Лазарев С.Д., Опарина Е.Е., Бычков В.Г. Цитогенез восстановления печени после частичной гепатэктомии на фоне суперинвазионного описторхоза. Регенераторная зона А // Актуальные вопросы диагностики и лечения наиболее распространенных заболеваний внутренних органов: Материалы IX терапевт. форума. Тюмень, 2017. С. 72-73.

9. Лазарев С.Д., Бычков В.Г., Чернов И.А. Динамика регенераторных процессов в печени после частичной гепатэктомии на фоне суперинвазионного описторхоза. Регенераторная зона C // Актуальные вопросы диагностики и лечения наиболее распространенных заболеваний внутренних органов: материалы X юбилейного терапевт. форума. Тюмень, 2018. C. 49-50.

10. Лазарев С.Д., Бычков В.Г., Галенко О.В. Гранулематозное воспаление печени после частичной гепатэктомии на фоне суперинвазионного описторхоза / Науч. конф. с междунар. участием, посвящ. 170-летию кафедры патологической анатомии им. акад. А.И. Струкова ФГАОУ ВО Первый МГМУ имени И.М. Сеченова Минздрава России (Сеченовский Университет): Сб. тезисов. Москва, 20 марта 2019 года. М., 2019. С. 39-40.

11. Higgins G.M., Anderson R.M. Experimental pathology of the liver. I. Restoration of the liver of the white rat following partial surgical removal // Arch. Pathol. 1931. Vol. 12. P. 186-202.

12. Бычков В.Г., Крылов Г.Г., Щудло М.М. и др. Влияние биотических факторов окружающей среды на здоровье человека Западной Сибири (на примере Opisthorchis felineus) // The III ${ }^{\text {rd }}$ Millenium - The New World: International Forum, December 2-6, Moscow: Труды Междунар. форума по проблемам науки, техники и образования. М., 2002. С. 86-93.

13. Пахарукова М.Ю. Структурно-функциональная организация метаболизма ксенобиотиков у возбудителя описторхоза Opisthorchis felineus (Rivolta, 1884): Автореф. дис. ... д-ра биол. наук. Новосибирск, 2016. $41 \mathrm{c}$.
3. Bychkov V.G., Kalyonova L.F., Khadieva E.D. et al. (2019). Dynamics of the $O$. felineus infestation intensity and egg production in carcinogenesis and partial hepatectomy in the setting of superinvasive opisthorchiasis. Anal. Cell. Path., ID 8078368.

4. Spirina Yu.S. (2020). The state of the bile ducts in superinvasive experimental opisthorchiasis. University Medicine of the Urals, 1 (2O), 7-8. In Russ.

5. Kozlova I.I., Zuevskiy V.P. (2020). Characteristics of granuloma formation in opisthorchis infestation and tuberculin allergization in experimental opisthorchiasis. Morphology, 157 (2-3), 103-104.

6. Kharitonova A.V., Zuevskaya T.V. (2020). Characteristics of granuloma formation following opisthorchis infestation and tuberculin allergization in experimental opisthorchiasis. Morphology, 157 (2-3), 225.

7. Lazarev S.D., Alekberov R.I. (2017). Features of liver regeneration after partial hepatectomy against the background of superinvasive opisthorchiasis. Regenerative zone $\mathrm{B}$. In $4^{\text {th }}$ International Medical Congress: Abstracts (pp. 41-42). Baku.

8. Lazarev S.D., Oparina E.E., Bychkov V.G. (2017). Cytogenesis of liver recovery after partial hepatectomy against the background of superinvasive opisthorchiasis. In Regeneration Zone A. Topical Issues of Diagnosis and Treatment of the Most Common Diseases of Internal Organs: Proceedings of the IX Therapeutic Forum (pp. 72-73). Tyumen. In Russ.

9. Lazarev S.D., Bychkov V.G., Chernov I.A. (2018). Dynamics of regenerative processes in the liver after partial hepatectomy against the background of superinvasive opisthorchiasis. Regeneration Zone C. In Topical Issues of Diagnosis and Treatment of the Most Common Diseases of Internal Organs: Proceedings of the X Anniversary Therapeutic Forum (pp. 49-50). Tyumen. In Russ.

10. Lazarev S.D., Bychkov V.G., Galenko O.V. (2019). Granulomatous inflammation of the liver after partial hepatectomy against the background of superinvasive opisthorchiasis. In Scientific Conf. with International Participation to mark Anniversary of the Pathologic Anatomy Department, Sechenov University: Collection of Abstracts (pp. 39-40). Moscow. In Russ.

11. Higgins G.M., Anderson R.M. (1931). Experimental pathology of the liver. I. Restoration of the liver of the white rat following partial surgical removal. Arch. Pathol., 12, 186-202.

12. Bychkov V.G., Krylov G.G., Shchudlo M.M. et al. (2002). Influence of biotic environmental factors on human health in Western Siberia (on the example of Opisthorchis felineus). In The III ${ }^{\text {rd }}$ Millenium - The New World: International Forum, December 2-6 (pp. 86-93). Moscow. In Russ.

13. Pakharukova M.Yu. (2016). Structural and functional organization of xenobiotic metabolism in the causative agent of opisthorchiasis Opisthorchis felineus (Rivolta, 1884): Thesis Dr. Sci. (Biol.). Novosibirsk, 41 p. In Russ.

\section{ABOUT THE AUTHORS}

Lazarev Semen Dmitriyevich - Assistant, Department of Pathological Anatomy and Forensic Medicine, Tyumen State Medical University. 


\section{СВЕДЕНИЯ ОБ АВТОРАХ}

Лазарев Семен Дмитриевич - ассистент кафедры патологической анатомии и судебной медицины ФГБОУ ВО «Тюменский государственный медицинский университет» Минздрава России.

Урузбаев Ринат Маратович - канд. мед. наук, доцент кафедры патологической анатомии и судебной медицины ФГБОУ ВО «Тюменский государственный медицинский университет» Минздрава России; врач-патологоанатом отделения онкоморфологии и высокотехнологичных методов исследования ГАУЗ ТО «МКМЦ «Медицинский город» (Тюмень).

Хадиева Елена Дмитриевна - канд. мед. наук, доцент кафедры патологической анатомии и судебной медицины БУ ВО ХМАО - Югры «ХантыМансийская государственная медицинская академия»; заведующий патолого-анатомическим отделением, врач-патологоанатом БУ ХМАО Югры «Окружная клиническая больница» (ХантыМансийск).

Куликова Светлана Витальевна - канд. мед. наук, доцент кафедры патологической анатомии и судебной медицины ФГБОУ ВО «Тюменский государственный медицинский университет» Минздрава России.

Косикина Анна Валерьевна - ординатор кафедры патологической анатомии и судебной медицины ФГБОУ ВО «Тюменский государственный медицинский университет» Минздрава России.

Вихарева Лариса Владимировна - д-р мед. наук, профессор, заведующий кафедрой анатомии человека, топографической анатомии и оперативной хирургии, руководитель Центра студенческой и молодежной науки ФГБОУ ВО «Тюменский государственный медицинский университет» Минздрава России.

Бычков Виталий Григорьевич - д-р мед. наук, заслуженный деятель науки РФ, профессор кафедры патологической анатомии и судебной медицины ФГБОУ ВО «Тюменский государственный медицинский университет» Минздрава России.

О бразец ци ти рования : Лазарев С.Д., Урузбаев Р.М., Хадиева Е.Д., Куликова С.В., Косикина А.В., Вихарева Л.В., Бычков В.Г. Гранулематоз как компонент пролиферативных реакций в печени и поджелудочной железе после частичной гепатэктомии на фоне суперинвазионного описторхоза // Journal of Siberian Medical Sciences. 2021. № 2. C. 65-76.
Uruzbaev Rinat Maratovich - Cand. Sci. (Med.), Associate Professor, Department of Pathological Anatomy and Forensic Medicine, Tyumen State Medical University; Pathologist, Department of Oncomorphology and High-Tech Research Methods, Clinical Medical Center "Medical City" (Tyumen).

Khadieva Elena Dmitriyevna - Cand. Sci. (Med.), Associate Professor, Department of Pathological Anatomy and Forensic Medicine, Khanty-Mansiysk State Medical Academy; Head, Pathologist, Pathology Department, District Clinical Hospital (Khanty-Mansiysk).

Kulikova Svetlana Vitalyevna - Cand. Sci. (Med.), Associate Professor, Department of Pathological Anatomy and Forensic Medicine, Tyumen State Medical University.

Kosikina Anna Valeryevna - Post-graduate Student, Department of Pathological Anatomy and Forensic Medicine, Tyumen State Medical University.

Vikhareva Larisa Vladimirovna - Dr. Sci. (Med.), Professor, Head, Department of Human Anatomy, Topographic Anatomy and Operative Surgery, Head, Center for Student and Youth Science, Tyumen State Medical University.

Bychkov Vitaliy Grigoryevich - Dr. Sci. (Med.), Honored Scientist of the Russian Federation, Professor, Department of Pathological Anatomy and Forensic Medicine, Tyumen State Medical University.

Citation example: Lazarev S.D., Uruzbaev R.M., Khadieva E.D., Kulikova S.V., Kosikina A.V., Vikhareva L.V., Bychkov V.G. (2021). Granulomatosis as a component of proliferative reactions in the liver and pancreas after partial hepatectomy in the setting of superinvasive opisthorchiasis. Journal of Siberian Medical Sciences, 2, 65-76. 